p-ISSN: $2338-4794$

e-ISSN: 2579-7476

Vol.7. No. 3 September-Desember 2019

\title{
PENGARUH KOMPETENSI DAN DISIPLIN KERJA TERHADAP KINERJA KARYAWAN PT. CHRISTALENTA PRATAMA
}

\author{
Willy Jermias Abdi ${ }^{1}$ ) \\ 1) Mahasiswa Program Studi Manajemen FE UNKRIS \\ Rasmansyah ${ }^{2}$ ) \\ 2) Dosen Program Studi Manajemen FE UNKRIS \\ Alamat: Kampus UNKRIS, Jatiwaringin Jakarta Timur \\ Email : $\underline{\text { rasmansyah31@ gmail.com }}$
}

\begin{abstract}
This study aims to determine: (1) the effect of competence on the performance of employees of PT. Christalenta Pratama, (2) the effect of work discipline on the performance of the employees of PT. Christalenta Pratama, and (3) simultaneous influence of competence and work discipline on the performance of the employees of PT. Christalenta Pratama. This research is causal associative research with quantitative approach. The population of this study is all employees of PT. Christalenta Pratama, amounting to 60 people. Data is collected by a questionnaire that has been tested for validity and reliability. The data analysis technique used is multiple regression. The results showed that: (1) there was a positive and significant effect of competence on the performance of the employees of PT. Christalenta Pratama; (2) there is a positive and significant influence of work discipline on the performance of employees of PT. Christalenta Pratama, and (3) there is a simultaneous influence of competence and work discipline on the performance of the employees of PT. Christalenta Pratama
\end{abstract}

Keywords: Competence, work discipline, and performance

\section{PENDAHULUAN}

Pelaksanaan tugas dengan baik, diperlukan pembinaan karyawan diarahkan untuk meningkatkan kualitas sumber daya manusia agar memiliki sikap dan perilaku yang berintikan pengabdian, kejujuran, tanggung jawab, disiplin serta wibawa sehingga dapat memberikan pelayanan sesuai tuntutan perkembangan masyarakat. SDM mempunyai peranan penting bagi organisasi karena sumber daya manusia sebagai pengelola sistem, agar sistem ini tetap berjalan, tentu dalam pengelolaannya harus memperhatikan aspek-aspek penting seperti kompetensi, disiplin kerja, pendidikan dan latihan serta tingkat kenyamanan bekerja sehingga karyawan yang bersangkutan dapat terdorong untuk memberikan segala kemampuan sesuai dengan yang dibutuhkan oleh organisasi. SDM dengan kinerja yang baik maka pada akhirnya akan menghasilkan kinerja karyawan yang baik pula.

Kinerja karyawan adalah "hasil kerja secara kualitas dan kuantitas yang dicapai oleh seorang karyawan dalam melaksanakan tugasnya sesuai dengan tanggung jawab yang diberikan kepadanya". Mangkunegara, (2013). Peningkatan kinerja merupakan hal terpenting yang diinginkan baik oleh karyawan maupun organisasi. Organisasi menginginkan kinerja karyawan yang optimal untuk kepentingan peningkatan hasil kerja dan keuntungan organisasi. 
Di sisi lain, karyawan berkepentingan untuk pengembangan diri dan promosi pekerjaan. Untuk memenuhi kedua keinginan tersebut, maka dibutuhkan sistem manajemen kinerja yang baik (Bangun, 2012).

Penelitian ini dilaksanakan di PT.

Christalenta Pratama Jakarta. Kinerja karyawan yang terdapat dalam PT. Christalenta Pratama merupakan hasil dari setiap kinerja karyawan yang berada di dalamnya yang telah diberikan tugas dan tanggung jawab. Oleh karena itu, kinerja karyawan PT. Christalenta Pratama secara keseluruhan akan tercermin dari hasil pencapaian kinerja PT. Christalenta Pratama dalam melaksanakan program kegiatan yang telah ditetapkan.

Dalam penelitian Setiawan dan Kartika (2014) diketahui bahwa karyawan yang memiliki kinerja yang tinggi ditandai dengan beberapa hal, antara lain: karyawan dapat menyelesaikan tugas dengan tepat dan cepat, karyawan bersedia mematuhi peraturan yang berlaku di perusahaan, karyawan sanggup bekerja dalam waktu yang sudah ditentukan, karyawan dapat bekerjasama dengan karyawan lain dalam menyelesaikan pekerjaan atau suatu tugas yang ditentukan oleh perusahaan. Namun pada kenyataannya, kinerja karyawan pada PT. Christalenta Pratama masih rendah.

Rendahnya kinerja karyawan PT. Christalenta Pratama ditunjukkan dari data sosialisasi mekanisme pelayanan .Berhasilnya pencapaian kinerja karyawan PT. Christalenta Pratama tidak terlepas dari kinerja Karyawan PT. Christalenta Pratama. Salah satu upaya instansi dalam mempertahankan kinerja karyawan adalah dengan cara memerhatikan kompetensi karyawan. Menurut Liestyodono dan Purwaningdyah (2008) kompetensi "merupakan pengetahuan, ketrampilan, dan kemampuan yang dikuasai oleh seseorang yang telah menjadi bagian dari dirinya, sehingga ia dapat melakukan perilaku-perilaku kognitif, afektif, dan psikomotorik dengan sebaik-baiknya" Menurut Simanjuntak (2005) "kompetensi dapat memperdalam dan memperluas kemampuan kerja". Semakin sering seseorang melakukan pekerjaan yang sama, semakin terampil dan semakin cepat pula dia menyelesaikan pekerjaan tersebut. Semakin banyak macam pekerjaan yang dilakukan seseorang, pengalaman kerjanya semakin kaya dan luas, dan memungkinkan peningkatan kerjanya. Sudarmanto (2011) mengatakan kompetensi sebagai atribut kualitas SDM berpengaruh signifikan terhadap kinerja individu.

Kompetensi menjelaskan apa yang dilakukan karyawan di tempat kerja pada berbagai tingkatan dan memperinci standar masing-masing tingkatan, mengidentifikasi karakteristik pengetahuan dan keterampilan yang diperlukan individual yang memungkinkan menjalankan tugas dan tanggung jawab secara efektif sehingga mencapai standar kualitas profesional dalam bekerja dan menghasilkan kinerja yang baik (Wibowo, 2009). Kompetensi karyawan dapat tercapai dengan cara memberikan pelatihan kepada karyawan yang sesuai dengan kebutuhan pekerjaannya dan tujuan organisasi.

PT. Christalenta Pratama memiliki karyawan dengan kompetensi yang tidak saling mendukung antara pendidikan yang dimiliki, pengalaman kerja, dan pelatihan. Menurut Romberg (1992) seorang karyawan memiliki kompetensi yang tinggi apabila "karyawan tersebut memiliki pengalaman kerja, latar belakang pendidikan yang mendukung profesi, memiliki keahlian/ pengetahuan, dan memiliki keterampilan". Namun berdasarkan pra survey yang dilakukan peneliti pada PT. Christalenta Pratama diketahui bahwa kompetensi karyawan 
masih rendah.

Faktor kedua yang memengaruhi kinerja karyawan adalah disiplin kerja. Kedisiplinan kerja dapat berdampak pada kehidupan pribadi karyawan yang berpengaruh terhadap perusahaan. Organisasi perlu mengawasi setiap tindakan dan perilaku yang dilakukan oleh karyawan saat bekerja. Jika ada tindakan penyelewengan yang tidak sesuai dengan aturan maupun sesuatu yang dianulir dari fakta yang ada sebaiknya perusahaan menetapkan hukuman bagi karyawannya. Atasan pun sebaiknya mengetahui dan melaksanakan aturan yang ada diperusahaan (Bellizzi dan Hasty, 2000). Menurut Masyjui (2005) dalam Sudarmanto (2011) "seorang karyawan yang memiliki disiplin kerja yang tinggi dapat dilihat dari: ketepatan waktu, menggunakan peralatan kantor dengan baik, tanggung jawab tinggi, dan ketaatan terhadap aturan kantor".

Tujuan penelitian ini adalah untuk mengetahui pengaruh kompetensi dan disiplin kerja terhadap kinerja karyawan PT. Chistalenta Pratama.

\section{LANDASAN TEORI}

\section{Kinerja}

Kinerja pegawai secara umum adalah sebuah perwujudan kerja yang dilakukan oleh karyawan yang biasanya digunakan sebagai dasar atau acuan penilaian terhadap karyawan didalam suatu organisasi. Kinerja yang baik merupakan suatu langkah untuk menuju tercapainya tujuan organisasi oleh karena itu, kinerja juga merupakan sarana penentu dalam mencapai tujuan organisasi sehingga perlu diupayakan untuk meningkatkan kinerja karyawan.

Wirawan (2009), menyampaikan kinerja adalah "keluaran yang dihasilkan oleh fungsi-fungsi atau indikatorindikator suatu pekerjaan atau suatu profesi dalam waktu tertentu". Hasibuan
(2006), mengemukakan kinerja adalah "suatu hasil kerja yang dicapai seseorang dalam melaksanakan tugas-tugas yang dibebankan kepadanya yang didasarkan atas kecakapan, pengalaman dan kesungguhan serta waktu". Mangkunegara (2013), menyatakan kinerja karyawan adalah "hasil kerja secara kualitas dan kuantitas yang dicapai oleh seorang karyawan dalam melaksanakan tugasnya sesuai dengan tanggung jawab yang diberikan kepadanya". Kesimpulannya adalah kinerja hasil kerja karyawan baik kualitas maupun kuantitas yang dicapai oleh karyawan dalam periode tertentu sesuai dengan tanggung jawab yang diberikan.

Wirawan (2009), mengatakan faktor-faktor yang memengaruhi kinerja antara lain: 1). "Faktor internal karyawan, yaitu faktor-faktor dari dalam diri karyawan yang merupakan faktor bawaan dari lahir dan faktor yang diperoleh ketika ia berkembang. Faktorfaktor bawaan, seperti bakat, sifat pribadi, serta keadaan fisik dan kejiwaan. Faktor-faktor yang diperoleh, seperti pengetahuan, keterampilan, etos kerja, pengalaman kerja, dan motivasi kerja. 2). Faktor lingkungan internal organisasi, yaitu dukungan dari organisasi dimana ia bekerja. Dukungan tersebut sangat memengaruhi tinggi rendahnya kinerja karyawan. Faktorfaktor lingkungan internal organisasi tersebut antara lain visi, misi dan tujuan organisasi, kebijakan organisasi, teknologi, strategi organisasi, sistem manajemen, kompensasi, kepemimpinan, budaya organisasi, dan teman sekerja. 3). Faktor lingkungan eksternal organisasi, yaitu keadaan, kejadian, atau situasi yang terjadi di lingkungan eksternal organisasi yang memengaruhi kinerja karyawan. Faktor-faktor lingkungan eksternal organisasi tersebut antara lain kehidupan ekonomi, kehidupan politik, kehidupan sosial, 
budaya dan agama masyarakat, dan kompetitor".

Setiawan dan Kartika (2014), mengatakan untuk mengukur kinerja dapat menggunakan indikator sebagai berikut: 1). "Ketepatan penyelesaian tugas merupakan pengelolaan waktu dalam bekerja dan juga ketepatan karyawan dalam menyelesaikan pekerjaan. 2). Kesesuaian jam kerja merupakan kesediaan karyawan dalam mematuhi peraturan perusahaan yang berkaitan dengan ketepatan waktu masuk/pulang kerja dan jumlah kehadiran. 3). Jumlah ketidakhadiran karyawan dalam suatu perusahaan selama periode tertentu. 4). Kerjasama antar karyawan merupakan kemampuan karyawan untuk bekerja sama dengan orang lain dalam menyelesaikan suatu tugas yang ditentukan sehingga mencapai daya guna dan hasil guna yang sebesar-besarnya".

\section{Kompetensi}

Sudarmanto (2011), "kompetensi sebagai pengetahuan keahlian, kemampuan, atau karakteristik pribadi individu yang mempengaruhi secara langsung kinerja pekerjaan”. Kompetensi menggambarkan dasar pengetahuan dan standar kinerja yang dipersyaratkan agar berhasil menyelesaikan suatu pekerjaan atau memegang suatu jabatan. Menurut Badan Kekaryawanan Negara (2003) kompetensi sebagai kemampuan dan karakteristik yang dimilki seseorang PNS yang berupa pengetahuan, keterampilan, dan sikap perilaku yang diperlukan dalam pelaksanaan tugas jabatannya, sehingga PNS tersebut dapat melaksanakan tugasnya secara professional, efektif, efisien. Secara terminologi kompetensi merupakan atribut untuk melekatkan sumber daya manusia yang berkualitas atau unggul. Atribut mengacu pada karakteristik tertentu untuk dapat melaksanakan pekerjaan secara efektif. Oleh karena atribut terdiri atas persyaratan pengetahuan, ketrampilan dan keahlian atau karakteristik tertentu. Ada yang menginteprestasikan kompetensi sepadan dengan kemampuan dan kecakapan. Adalagi yang menginteprestasikan sepadan dengan ketrampilan, pengetahuan dan berpendidikan tinggi.

Zwell (2000), menyampaikan kompetensi seseorang dapat dipengaruhi oleh beberapa faktor antara lain: 1). "Keyakinan dan nilai-nilai. Perilaku seseorang sangat dipengaruhi oleh keyakinannya terhadap dirinya sendiri dan orang lain. Bila orang percaya akan kemampuannya dalam melakukan sesuatu, maka hal tersebut akan bisa dikerjakan dengan lebih mudah. 2). Karakteristik kepribadian. Kepribadian bukanlah sesuatu yang tidak dapat dirubah, kepribadian seseorang akan mempengaruhi cara-cara orang tersebut dalam menyelesaikan permasalahan dalam kehidupan ini, dan hal ini akan membuat orang tersebut lebih kompeten. Seseorang akan berespons serta beradaftasi dengan lingkungan dan kekuatan sekitarnya, yang akan menambah kompetensi seseorang. 3). Motivasi. Motivasi adalah dorongan yang membuat seseorang mampu untuk melakukan sesuatu. Daya dorong yang lebih bersifat psikologis membuat bertambahnya kekuatan fisik, sehingga akan mempermudah dalam aktivitas kerja, yang menambah tingkat kompetensi seseorang. Dorongan atau motivasi yang diberikan atasan kepada bawahan juga berpengaruh baik terhadap kinerja staf. 4). Isu emosional. Kondisi emosional seseorang akan berpengaruh dalam setiap penampilannya, termasuk dalam penampilan kerjanya. Rasa percaya diri membuat orang akan dapat melakukan suatu pekerjaan dengan lebih baik, begitu juga sebaliknya, gangguan emosional seperti rasa takut dan malu 
juga bisa menurunkan performancel penampilan kerja seseorang, sehingga kompetensinya akan menurun. 5). Kemampuan intelektual. Kompetensi dipengaruhi oleh pemikiran intelektual, kognitif, analitis dan kemampuan konseptual. Tingkat intelektual dipengaruhi oleh pengalaman, proses pembelajaran yang sudah tentu pula kemampuan intelektual seseorang akan meningkatkan kompetensinya. 6). Budaya organisasi. Budaya organisasi berpengaruh pada kompetensi seseorang dalam berbagai kegiatan, karena budaya organisasi mempengaruhi kinerja, hubungan antar karyawan, motivasi kerja dan kesemuanya itu akan berpengaruh pada kompetensi orang tersebut".

$\begin{array}{llr}\text { Indikator } & \begin{array}{l}\text { Kompetensi menurut } \\ \text { Sutrisno }\end{array} & \begin{array}{r}\text { mog9) } \\ \text { adalah: }\end{array}\end{array}$

1). "Pengalaman kerja suatu dasar/acuan seorang karyawan dapat menempatkan diri secara tepat kondisi, berani mengambil risiko, mampu menghadapi tantangan dengan penuh tanggung jawab serta mampu berkomunikasi dengan baik terhadap berbagai pihak untuk tetap menjaga produktivitas, kinerja dan menghasilkan individu yang kompeten dalam bidangnya. 2). Pendidikan adalah suatu kegiatan untuk meningkatkan penguasaan teori dan keterampilan memutuskan terhadap persoalanpersoalan yang menyangkut kegiatan guna mencapai tujuan. Upaya ini dilakukan untuk memperbaiki kontribusi produktif para karyawan dan mengembangkan sumber daya manusia menghadapai segala kemungkinan yang terjadi akibat perubahan lingkungan". 3). Pengetahuan adalah pengetahuan atau informasi seseorang dalam bidang spesipik tertentu. 4). Keterampilan adalah kemampuan untuk melaksanakan tugas fisik tertentu atau tugas mental tertentu".

\section{Disiplin Kerja}

Disiplin merupakan bagian dari fungsi operasional MSDM yang terpenting karena semakin baik disiplin karyawan, semakin tinggi prestasi kerja yang dapat dicapainya.Tanpa disiplin karyawan yang baik, sulit bagi organisasi perusahaan atau instansi mencapai hasil yang optimal. Kedisiplinan merupakan fungsi operasional manajemen sumber daya manusia yang terpenting karena semakin baik disiplin kerja karyawan, semakin baik kinerja yang dapat dicapai.Tanpa disiplin yang baik, sulit bagi organisasi untuk mencapai hasil yang optimal. Kedisiplinan merupakan faktor yang utama yang diperlukan sebagai alat peringatan terhadap karyawan yang tidak mau berubah sifat dan perilakunya. Sehingga seorang karyawan dikatakan memiliki disiplin yang baik jika karyawan tersebut memiliki rasa tanggung jawab terhadap tugas yang diberikan kepadanya.

Simamora (2004), menyatakan disiplin adalah "prosedur yang mengoreksi atau menghukum bawahan karena melanggar peraturan atau prosedur". Hasibuan (2013), menyampaikan bahwa "disiplin kerja adalah kesadaran dan kerelaan seseorang dalam menaati semua peraturan perusahaan dan norma-norma sosial yang berlaku". Rivai (2011), mengemukakan bahwa: "disiplin kerja adalah suatu alat yang dipergunakan para manajer untuk berkomunikasi dengan karyawan agar mereka bersedia untuk mengubah suatu perilaku serta sebagai suatu upaya untuk meningkatkan kesadaran dan kesedian seorang dalam memenuhi segala peraturan perusahaan." Singodimenjo dalam Sutrisno (2009:86) bahwa: "Disiplin adalah sikap kesediaan dan kerelaan seseorang untuk mematuhi dan mentaati norma-norma peraturan yang berlaku di sekitarnya".

Menurut Singodimedjo dalam 
Sutrisno (2009), mengemukakan faktor yang mempengaruhi disiplin kerja karyawan adalah: 1). "Besar kecilnya pemberian kompensasi. Besar kecilnya kompensasi dapat mempengaruhi tegaknya disiplin. Para karyawan akan mematuhi segala peraturan yang berlaku, bila ia merasa mendapat jaminan balas jasa yang setimpal dengan jerih payahnya yang telah dikontribusikannya bagi perusahaan. 2). Ada tidaknya keteladanan pimpinan dalm perusahaan. Keteladanan pimpinan sangat penting sekali, karena dalam lingkungan perusahaan, semua karyawan akan selalu memperhatikan bagaimana pimpinan dapat menegakkan disiplin dirinya dan bagaimana ia dapat mengendalikan dirinya sendiri ucapan, perbuata, dan sikap yang dapat merugikan aturan disiplin yang sudah ditetapkan. 3). Ada tidaknya aturan pasti yang dapat dijadikan pegangan. Pembinaan disiplin tidak akan dapat terlaksana dalam perusahaan, bila tidak ada aturan tertulis yang pasti untuk dapat dijadikan pegangan bersama. 4). Keberanian pimpinan dalam mengambil tindakan. Bila ada seseorang karyawan yang melanggar disiplin, maka perlu ada keberanian pimpinan untuk mengambil tindakan yang sesuai dengan pelanggaran yang dibuatnya. 5). Ada tidaknya pengawasan pimpinan. Dalam setiap kegiatan yang dilakukan oleh perusahaan perlu ada pengawasan, yang akan mengarahkan para karyawan agar dapat melaksanakan pekerjaan dengan tepat dan sesuai dengan yang telah ditetapkan. 6). Ada tidaknya perhatian kepada karyawan. Karyawan adalah manusia yang mempunyai perbedaan karakter antara yang satu dengan yang lain. 7). Diciptakan kebiasaan-kebiasaan yang nendukung tegaknya disiplin. Disiplin adalah sikap kesedian dan kerelaan seseorang untuk mematuhi dan menaati norma-norma peraturan yang berlaku disekitarnya. Disiplin karyawan yang baik akan mempercepat tujuan perusahaan, sedangkan disiplin yang merosot akan menjadi penghalang dan memperhambat pencapaian tujuan perusahaan. Disiplin sangat diperlukan baik individu yang bersangkutan maupun oleh organisasi”.

Sudarmanto (2011) indikator dari disipilin kerja yaitu: 1). "Ketepatan waktu: para karyawan datang ke kantor tepat waktu, tertib dan teratur, dengan begitu dapat dikatakan disiplin kerja baik. 2). Menggunakan peralatan kantor dengan baik: sikap hati-hati dalam menggunakan peralatan kantor, dapat menunjukan bahwa seseorang memiliki disiplin kerja baik, sehingga peralatan kantor dapat terhindar dari kerusakan. 3). Tanggung jawab tinggi: karyawan yang senantiasa menyelesaikan tugas yang dibebankan kepadanya sesuai dengan prosedur dan tanggung jawab atas hasil kerja, dapat pula dikatakan memiliki disiplin kerja yang baik. 4). Ketaatan terhadap aturan kantor: karyawan memakai seragam kantor, menggunakan kartu tanda pengenal/ identitas, membuat ijin bila tidak masuk kantor, juga merupakan cerminan disiplin yang tinggi”.

\section{METODE PENELITIAN}

Jenis penelitian yang digunakan adalah jenis penelitian penjelasan (explanatory research). Secara umum metode penelitian diartikan sebagai cara ilmiah untuk mendapatkan data dengan tujuan dan kegunaan tertentu. Cara ilmiah berarti kegiatan penelitian itu didasarkan pada ciri-ciri keilmuan, yaitu rasional, empiris dan sistematis. Rasional berarti kegiatan itu dilakukan dengan cara-cara yang masuk akal, sehingga terjangkau oleh penalaran manusia. Empiris berarti cara-cara yang dilakukan tersebut dapat diamati oleh indra manusia, sehingga orang lain dapat mengamati dan mengetahui cara-cara 
yang digunakan. Alasan memilih jenis penelitian penjelasan explanatory research adalah untuk menguji hipotesis yang diajukan. Dengan hipotesis tersebut diharapkan dapat menjelaskan hubungan dan pengaruh antara variabel. Pendekatan yang digunakan dalam penelitian ini adalah pendekatan kuantitatif. Dalam penelitian jenis ini, selanjutnya dilakukan analisis pengaruh antara variabel-variabel yang telah dirumuskan, yaitu lingkungan kerja dan motivasi kerja terhadap kinerja karyawan.

Populasi dalam penelitian ini adalah seluruh karyawan PT. Christalenta Pratama yang berjumlah 60 orang. Penelitian ini disebut sampel junuh karena seluruh anggota populasi sebanyak 60 orang dijadikan responden sampel penelitian.

Metode analisis dengan menggunakan regresi linear sederhana mapun berganda dan pengujian hipotesis secara bersama-sama (uji F) dan secara parsial (uji t).

\section{HASIL PENELITIAN DAN PEMBAHASAN}

Tabel 1. Hasil-Hasil Output Mengenai Regresi.

\begin{tabular}{|c|c|c|c|c|c|}
\hline $\begin{array}{c}\text { Hubungan } \\
\text { Variabel }\end{array}$ & $\begin{array}{c}\mathbf{R} \\
\text { Square }\end{array}$ & Constant & $\begin{array}{c}\text { Koefisien } \\
\text { Regresi }\end{array}$ & $\mathbf{t}$ & $\mathbf{F}$ \\
\hline $\begin{array}{l}\text { Kompetensi dan } \\
\text { Kinerja }\end{array}$ & 0,496 & 11,536 & 0,667 & 7,557 & 57,118 \\
\hline $\begin{array}{l}\text { Disiplin kerja dan } \\
\text { Kinerja }\end{array}$ & 0,527 & 9,119 & 0,717 & 8,045 & 64,733 \\
\hline $\begin{array}{l}\text { Kompetensi, } \\
\text { Disiplin kerja, dan } \\
\text { Kinerja }\end{array}$ & 0,615 & 6,234 & $\begin{array}{l}0.456 \\
0,376\end{array}$ & - & 45,474 \\
\hline
\end{tabular}

\section{Persamaan Regresi Linear Sederhana Variabel Kompetensi}

Pada Tabel 1, Nilai koefisien determinasi kompetensi sebesar 0,496 atau perubahan kinerja sebesar 49,6\% disumbangkan oleh kompetensi, sisanya sebesar 50,4\% disumbangkan oleh faktor lainnya yang tidak dimasukkan dalam penelitian ini. Nilai koefisien regresi kompetensi sebesar 0,667, sehingga untuk persamaan regresi linear sederhana untuk kompetensi $\mathrm{Y}=11,536+0,667$ $\mathrm{X}_{1}$, yang menunjukkan adanya koefisien garis regresi yang positip. Hal ini berarti koefisiensi regresi kompetensi sebesar 0,667 memberikan indikasi bahwa jika terjadi perubahan kompetensi satu kali, kinerja akan berubah sebesar 0,677 kali. Maknanya, kompetensi memiliki hubungan dan pengaruh yang positip terhadap kinerja.

\section{Persamaan Regresi Linear Sederhana Variabel Disiplin Kerja}

Pada Tabel 1, Nilai koefisien determinasi disiplin kerja sebesar 0,527 atau perubahan kinerja sebesar $52,7 \%$ disumbangkan oleh disiplin kerja, sisanya sebesar $47,3 \%$ disumbangkan oleh faktor lainnya yang tidak dimasukkan dalam penelitian ini. Nilai koefisien regresi disiplin kerja sebesar 0,717 , sehingga untuk persamaan regresi linear sederhana untuk disiplin kerja $\mathrm{Y}$ $=9,119+0,717 X_{2}$, yang menunjukkan adanya koefisien garis regresi yang positip. Hal ini berarti koefisiensi regresi disiplin kerja sebesar 0,717 memberikan indikasi bahwa jika terjadi perubahan disiplin kerja satu kali, kinerja akan 
berubah sebesar 0,717 kali. Maknanya, disiplin kerja memiliki hubungan dan pengaruh yang positip terhadap kinerja.

\section{Persamaan Regresi Linear Berganda Variabel Kompetensi dan Disiplin Kerja}

Pada Tabel 1, Nilai $\mathrm{F}$ hitung $>\mathrm{F}$ tabel, 45.474 > 3,159 berarti melalui uji simultan kompetensi, dan disiplin memiliki hubungan dan pengaruh yang signifikan terhadap kinerja karyawan, hal tersebut memberikan makna ada pengaruh yang signifikan antara kompetensi, dan disiplin kerja dengan kinerja karyawan. Nilai koefisien determinasi sebesar 0,615, konstribusi yang diberikan kompetensi dan disiplin kerja kepada kinerja karyawan sebesar $61,5 \%$, sisanya sebear $38,5 \%$ disumbangkan oleh faktor lainnya yang tidak dimasukan dalam penelitian ini.

Dari hasil perhitungan diperoleh nilai persamaan regresi berganda sebagai berikut :

$$
\mathrm{Y}=6,234+0.456 \mathrm{X}_{1}+0,376 \mathrm{X}_{2}+\mathrm{e}
$$

Berdasarkan persamaan yang terbentuk pada Tabel 1, Koefisien regresi berganda kompetensi dan disiplin dapat diinterpretasikan bahwa dari koefesien regresi tersebut kompetensi $\left(b_{1}\right)$, mendorong perubahan kinerja sebesar 0.456 kali, disiplin $\left(b_{2}\right)$ mendorong perubahan kinerja sebesar 0.376 kali, jika terjadi perubahan kompetensi dan disiplin kerja satu kali, maka dapat kompetensi dan disiplin kerja memberikan pengaruh yang positif dan signifikan terhadap kinerja karyawan.

\section{KESIMPULAN DAN SARAN}

\section{Kesimpulan}

Dari hasil perhitungan, analisis dan pembahasan mengenai kompetensi, dan disiplin kerja terhadap kinerja karyawan PT. Christalenta Pratama, dapat ditarik kesimpulan sebagai berikut: 1). Terdapat pengaruh positif dan signifikan kompetensi terhadap kinerja karyawan PT. Christalenta Pratama. 2). Terdapat pengaruh positif dan signifikan disiplin kerja terhadap kinerja karyawan PT. Christalenta Pratama. 3). Terdapat pengaruh yang signifikan kompetensi dan disiplin kerja secara bersama-sama terhadap kinerja karyawan PT. Christalenta Pratama.

\section{Saran}

Berdasarkan kesimpulan dalam memelihara dan meningkatkan kinerja karyawan PT. Christalenta Pratama. disarankan sebagai berikut: 1). Kebijaksanaan Pimpinan PT. Christalenta Pratama. yang kaitannya dengan kinerja karyawan agar tetap dipertahankan dan ditingkatkan serta tetap terpelihara dan tujuan organisasi bisa tercapai lebih baik lagi dan akhirnya akan meningkatkan kinerja karyawan. 2). Kebijaksanaan pimpinan PT. Christalenta Pratama. dalam melakukan kompetensi tetap dipertahankan kalau perlu ditingkatkan kembali agar kinerja karyawan menjadi lebih baik lagi. 3). Kebijaksanaan pimpinan dalam memberi disiplin kerja harus lebih ditingkatkan agar kinerja menjadi bertambah lebih baik. 4). Perlu kiranya diadakan penelitian lanjutan yang berhubungan dengan aspek-aspek kompetensi dan disiplin kerja terhadap kinerja di luar variabel yang telah diteliti sekarang.

\section{DAFTAR PUSTAKA}

Arikunto, Suharsimi. 2010. Prosedur Penelitian. Jakarta: Rineka Cipta. Bangun, Wilson. 2012. Manajemen Sumber Daya Manusia. Bandung: Erlangga.

Bellizzi, Joseph A, Ronald W Hasty. 2000. "The Effects of Hiring Decisions on The Level of 
Discipline Used in Response to Poor Performance". International Journal of Business and Management. Vol.38,No.3,p. 154.

BPS United Nation Population Fund. 2015. Analisis Korelasi dan Regresi Linier. Artikel. Jakarta.

Ghozali, Imam. 2016. Aplikasi Analisis Multivariete: Dengan Program IBM SPSS 23. Semarang. Badan Penerbit Universitas Diponegoro.

Hasibuan, Malayu S.P. 2006. Manajemen Sumber Daya Manusia, Cetakan Kedelapan. Jakarta: PT. Bumi Aksara.

Liestyodono dan Purwaningdyah. 2008. "Meningkatkan Kompetensi Aparatur Pemerintah Daerah Dalam Mewujudkan Good Governance". Jurnal Kebijakan dan Manajemen PNS Pusat Pengkajian dan Penelitian Kepegawaian BKN.

Mangkunegara, A. A, Anwar Prabu. 2013. Evaluasi Kinerja Sumber Daya Manusia. Bandung: Refika Aditama.

Rivai, Veithzal. 2011. Manajemen Sumber Daya Manusia Untuk Perusahaan Dari Teori ke Praktik. Jakarta: Raja Grafindo Persada.

Romberg, T.A. 1992. Perspective on Scholarship and Research Methods. In D. A Grouws (Ed), Handbook of research on mathematics teaching and learning: A Project of the NCTM, (PP. 59-64) New York: Macmillani Publishing Companyu.
Setiawan, Ferry dan Dewi, Kartika. 2014. "Pengaruh Kompensasi Dan Lingkungan Kerja Terhadap Kinerja Karyawan pada CV. Berkat Anugrah." Jurnal. Denpasar: Universitas Udayana.

Simamora, H. 2004. Manajemen Sumber Daya Manusia. Yogyakarta: STIE YKPN.

Simanjuntak, Payaman J. 2005. Manajemen dan Evaluasi Kinerja. Jakarta: Lembaga Penerbit Fakultas Ekonomi UI.

Sudarmanto. 2011. Kinerja dan Pengembangan Kompetensi SDM Teori, Dimensi dan Implementasi dalam Organisasi. Yogyakarta; Pustaka Pelajar.

Sugiyono. 2016. Statikstika Untuk Penelitian. Bandung. Penerbit Alfabeta.

Sutrisno, Edi. 2009. Manajemen Sumber Daya Manusia Edisi pertama. Jakarta: Kencana Prenada Media Group.

Wibowo. 2009. Manajemen Kinerja. Jakarta: Penerbit PT. Raja Grafindo.

Wirawan. 2009. Evaluasi Kinerja Sumber Daya Manusia. Jakarta: Erlangga.

Zwell, Michael. 2000. Creating a Culture of Competence. New York: John Wiley \& Sons, Inc 